\title{
Indopiptadenia oudhensis (Endangered Plant): A New Host of Foliar Pathogen Alternaria alternata from Uttar Pradesh, India
}

\section{Kumar $\mathbf{S}^{1 *}$, Singh $\mathbf{R}^{2}$ and Maurya $\mathbf{V K}^{3}$}

${ }^{1}$ Herbarium Division, Birbal Sahni Institute of Palaeobotany, 53, University Road, Lucknow-226007 (U.P.), India

${ }^{2}$ Department of Botany, School of Biological Sciences, Dr. Harisingh Gour Central University, Sagar-470003 (M.P.), India

${ }^{3}$ Department of Botany and Microbiology, School of Biological Sciences, HNB Garhwal Central University, Srinagar, Garhwal-246174, Uttarakhand, India

\begin{abstract}
A severe leaf spot disease of Indopeptadenia oudhensis (Mimosaceae) caused by Alternaria alternata (Fr.) Keissler was observed for the first time in Lucknow, Uttar Pradesh province of India between 2012-2013 based on morphological characteristics and pathogenicity. This is the first report as new host for foliar pathogen Alternaria alternata for science.
\end{abstract}

Keywords: Foliar disease, Indopiptadenia oudhensis, Alternaria alternata, New host record

\section{Introduction}

Indopiptadenia oudhensis (Brandis) Brenan is a monotypic angiosperm plant belongs to family Mimosaceae. The plant is medium sized tree having bi-pinnate leaves with long stalks. Presently the plant standing at the verge of extinction as notified by the Central Government of India, in consultation with the Govt. of Uttar Pradesh vide its notification no. S.O.998 E, dated 15-04-2009 and has prohibited and regulated its collection in order to conserve the species. It is found naturally in U.P., India in the Sohelwa Wildlife Forest Division, Balrampur and now cultivated in garden. The plant is commonly known as Gainti, Hath Paula and the rapid depletion of the lovely species from the planet earth's flora in the recent years from various meetings, seminars and from the friend and well-wishers, who are seriously concerned about the tree.

\section{Objectives}

The main purpose of this study was to identify the fungus causing leaf spot disease on this endangered plant in our garden and to confirm its pathogenicity on the host.

\section{Materials and Methods}

The diseased plant was regularly observed between September 2012-2013 (i.e. the fungal disease observed in season in 2012 and reobserved again in 2013) and infected leaf samples were collected from BSIP Garden, Lucknow $\left(26.8656^{\circ} \mathrm{N}, 80.9364^{\circ} \mathrm{E}\right)$. The fungal specimens carried to the laboratory and processed in the form of dried herbaria by the standard techniques. Photographs of infection spots on the host leaf were taken by using a Sony DSC-5730 camera. Specimens for microscopic observation were prepared by hand, cut section and scraps from the infected part and the slides were mounted in water and lacto-phenol mount mixture. Observations were made with an Olympus BX-51 light microscope by using the Syntek USB camera. Morphotaxonomic determinations have been made by comparing with the closely related taxa in question and by consulting the current literature pertaining to the taxonomy of Alternaria. The dried specimen of Alternaria alternata has been deposited in the Ajrekar Mycological Herbarium, (AMH-MACS-ARI), Agharkar Research Institute, Pune, India (Accession No. AMH-9640) and a part of the same was retained in BSIP Herbarium (BSIPMH-28), Lucknow, India.

\section{Observation and Discussion}

The host symptoms, sporulation pattern, conidiophores and conidial morphology were examined and upon morphological observation the fungus shows following characteristics as:

The symptoms of disease initially began from the margin of the leaves as small light brown circular to sub circular spots (Figure 1A1C). In severe infection leaves several spots coalesced to form larger necrotic areas, resulting leading to drying and falling of the leaves.

Anamorphic fungus, Foliicolous, Infection spots amphigenous, circular, sub circular to irregular, brown, up to $5 \mathrm{~mm} \mu \mathrm{m}$ in diam. Colonies amphiphyllous, effuse, brown. Mycelium internal. Stromata present, $15 \mu \mathrm{m}$ in diam. Conidiophores macronematous, fasciculatous, 2-7 in a fascicle, straight to flexuous, simple, cylindrical, unbranched, thick walled, smooth, 1-3 septate, brown, 10-53 $\times 3-5 \mu \mathrm{m}$. Conidiogenous cells integrated, terminal, polytretic, scars thickened. Conidia simple, acropleurogenous, solitary to catenate, dry, obclavate to ellipsoidal to ovoid, rostrum present, 2-4 transversely septate and 2-3 obliquely septate, brown, base obtuse, 20-50 $\times 10-20 \mu \mathrm{m}$, hilum thickened (Figure 2).

\section{Material Examined}

India, (U.P.), Lucknow, BSIP Garden, on living leaves of Indopeptadenia oudhensis (Mimosaceae), $2^{\text {nd }}$ September, 2012, coll. Shambhu Kumar, AMH-9640, BSIPMH-28.

The distinct diseased leaves were cut into little fragments, surface sterilized in $1 \%$ sodium hypochlorite for 2 minutes, washed three times in sterile distilled water, and plated on potato dextrose agar (PDA), and then incubated at $25^{\circ} \mathrm{C}$ for 5-7 days under a $12 \mathrm{~h}$ light and dark conditions. Hyphal tips from the margin of each developing colony were sub-cultured on PDA. Fungal colonies were initially white, becoming olivaceous, and turning brown with age.

For determination of pathogenicity test, inoculations were performed on detached, surface sterilized, healthy leaves following by

*Corresponding author: Kumar S, 1Herbarium Division, Birbal Sahni Institute of Palaeobotany, 53, University Road, Lucknow-226007 (U.P.), India, Tel: +919935110159; E-mail: skumartaxon@gmail.com

Received May 29, 2015; Accepted June 24, 2015; Published June 28, 2015

Citation: Kumar S, Singh R, Maurya VK (2015) Indopiptadenia oudhensis (Endangered Plant): A New Host of Foliar Pathogen Alternaria alternata from Utta Pradesh, India. J Plant Pathol Microbiol S3: 004. doi:10.4172/2157-7471.S3-004

Copyright: ๑ 2015 Kumar S, et al. This is an open-access article distributed under the terms of the Creative Commons Attribution License, which permits unrestricted use, distribution, and reproduction in any medium, provided the original author and source are credited. 
Citation: Kumar S, Singh R, Maurya VK (2015) Indopiptadenia oudhensis (Endangered Plant): A New Host of Foliar Pathogen Alternaria alternata from Uttar Pradesh, India. J Plant Pathol Microbiol S3: 004. doi:10.4172/2157-7471.S3-004

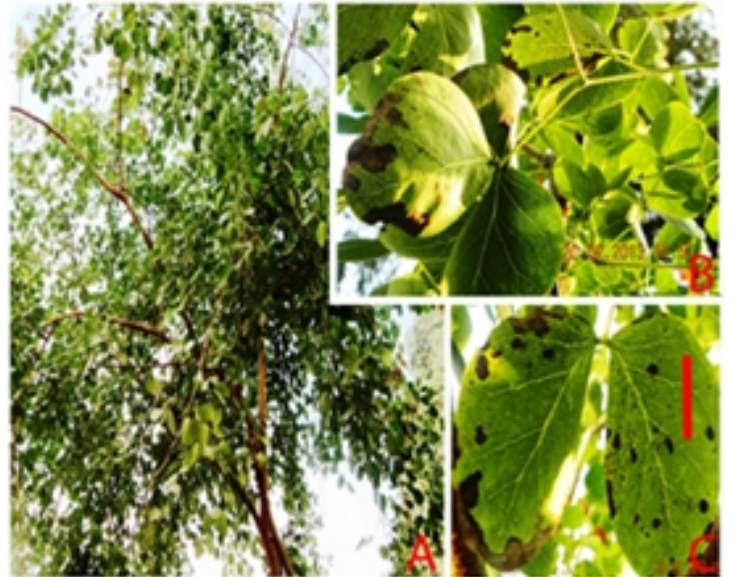

Figure 1: Leaf spot symptoms on endangered plant (Indopiptadenia oudhensis). A: Host plant habitat; B and C: on the underside of the leaf, many brown colour circular, sub-circular to irregular leaf spot appears, A, B, C=20 $\mathrm{mm}$.

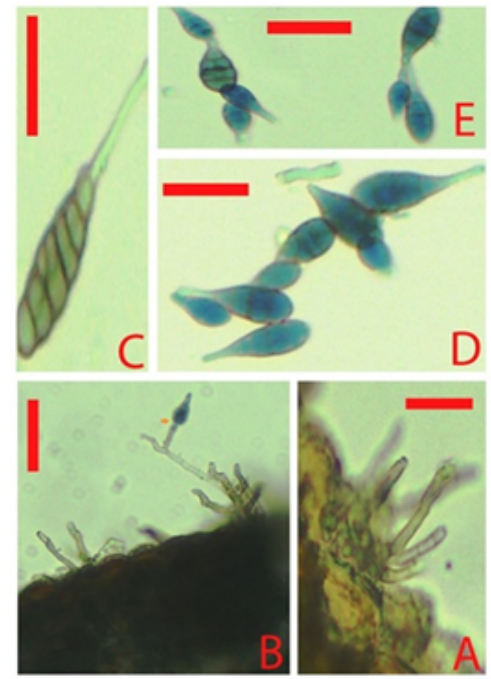

Figure 2: Alternaria alternata (causal agent) of leaf spot disease on endangered plant (Indopiptadenia oudhensis). A: host-pathogen interaction showing conidium attached on conidiophore (arrow indicating) formed on host epidemis; B: tufts of conidiophores and stroma on sub-epidermal position; C: Single conidium; D, E: Chains of conidia; Scale bars A, B, C, D, E=20 $\mu \mathrm{m}$.

the Belisario method [1]. 10 leaves per isolates were used to experiment. A $5-\mu \mathrm{l}$ drop of conidial suspension containing $1 \times 10^{5} \mathrm{CFU} / \mathrm{ml}$ was placed on each leaf. The leaves were incubated in a growth chamber (90\% relative humidity and a $12-\mathrm{h}$ photoperiod). After 5-7 days, leaf spots similar to the original symptoms developed on all inoculated leaves and the pathogen A. alternata was consistently re-isolated from symptomatic tissue, fulfilling Koch's postulates. The Control leaves, however inoculated with sterile distilled water remained asymptomatic (symptomless) or without infection.

On the basis of external symptomatology, fungus morphological characteristics, and pathogenicity the pathogen was identified as Alternaria alternata (Fr.) Keissler [2,3], an ubiquitous fungal pathogen reported globally on different hosts, but according to the current literatures, no any fungus has been reported to cause leaf spot diseases on Indopeptadenia oudhensis from all over the world particularly from India [4-12]. To the best of our knowledge, the leaf spot disease of Indopiptadenia oudhensiscaused by A. alternata is the first report from India as well as for science and the occurrence of present leaf spot disease on endangered plant is very interesting and significant to control measures.

\section{Acknowledgement}

Authors' are thankful to the Director, Birbal Sahni Institute of Palaeobotany for providing infrastructure facilities. The authors' express their sincere gratitude to Dr. D.C. Saini, Scientist F of the Birbal Sahni Institute of Palaeobotany, Lucknow, for identification of host plant. We would like to thank both anonymous reviewers for comment and suggestions. Science and Engineering Research Board (SERB), Department of Science and Technology (DST), Government of India, New Delh for financial assistance as Fast Track Young Scientist Start-Up project (SB/YS/ LS-288/2013)

\section{References}

1. Belisario A, Forti E, Corazza L, Van Kesteren HA (1999) First report of Alternaria alternata causing leaf spot on English walnut. Plant Disease 83: 696.

2. Ellis MB (1971) Dematiaceous Hyphomycetes. Kew: Commonwealth Mycological Institute.

3. Simmons EG (2007) Alternaria: An identification manual. The American Phytopathological Society, St. Paul, MN

4. Bilgrami KS, Jamaluddin, Rizwi MA (1979) Fungi of India I. List andreferences, New Delhi, p. 467.

5. Bilgrami KS, Jamaluddin, Rizwi MA (1981) Fungi of India II. HostIndex and Addenda.Today's and Tomorrow's Printer's and Publisher's, New Delhi, p. 128.

6. Bilgrami KS, Jamaluddin, Rizwi MA (1991) Fungi of India. List and references. Today's and Tomorrow's Printer's and Publisher's, New Delhi, p. 798.

7. Butler EJ, Bisby GR (1954) Fungi of India (Revised by R. S.Vasudeva). Indian Agriculural Research Institute, New Delhi, p. 552.

8. Jamaluddin, Goswami MG, Ojha BM (2004) Fungi of India 1989-2001, Scientific Publishers, Jodhpur, India. p. 326

9. Farr DF, Rossman AY (2014) Fungal Databases, Systematic Mycology and Microbiology Laboratory, ARS, USDA. Retrieved February 6, 2015, from http:// nt.ars-grin.gov/fungaldatabases/

10. Sarbhoy AK, Agarwal DK, Varshney JL (1986) Fungi of India (1977-1981). Associated Publishing Company, New Delhi, p. 274

11. Sarbhoy AK, Agarwal DK, Varshney JL (1996) Fungi of India (1982-1992). CBS Publishers and Distributors, New Delhi, p. 350.

12. Sarbhoy AK, Lal G, Varshney JL (1975) Fungi of India (revised) 1967-1971. Navyug Traders Bookseller \& Publishers, New Delhi, p. 148. 